\title{
Analysis of Employment and Economic Patriotism : A Case of Nepal
}

\author{
- Baikuntha Pandey*
}

\begin{abstract}
Deficiency in demand is the host of almost all economic problems in the modern world. Economic growth and rate of employment have positive relations, but productivity of workers inversely affects the employment growth. Employment challenge in a developing country like Nepal may manifest in several forms. Firstly, there is a quantitative dimension in employment that employment growth may fall short of labour force growth giving rise to open unemployment. Secondly, low productivity earnings associated with a sizeable segment of the employed population is another form. Eemployment patriotism is the judicial blend of employment and economic patriotism. Every government action is needed to be guided by employment generation motives. In addition to the increased pressure due to an unprecedented volume of COVID-19 induced returnees, the economic downturn due to the pandemic may also reduce the global demand for migrant workers. In such an alarming case, Nepal needs to prepare for employment patriotism policy.
\end{abstract}

Key Words: deficiency, employment, patriotism, COVID-19, judicial blend, returnee migrant

\section{Introduction}

Economic crisis emerges from lack of employment opportunity which is rooted from demand constraints. People's purchasing power is reduced when they lose jobs or when they do not get job opportunity at all. With the reduced purchasing trend, entrepreneurs are not excited to invest. As a result, the manufacturers resort to cutting down the labourers from the jobs. Now, the new situations come up: buying capacity of the labourers deteriorates and the aggregate demand further declines. Hence, the economy plunges into a ditch with endless income-demand spiral. So, to say, employment of human resources forges all dimensions of a society and gives a new shape to it. Thus, the aggregate demand is required to maintained through any means. Employment helps absorbing or utilizing physical as well as natural resources. When the human resources are diverted to productive channels, a nation's economic transformation becomes obvious.

Employment leads improved welfare of the workers and hence their productivity also will be improved due to their ability to maintain esteemed living standard. Many developing countries have found to have tended to neglect agriculture sector. Developing countries like Nepal have no option but to expand employment opportunities in the agriculture sector. Agriculture planning strategy has not been adopted properly in Nepal. Agriculture planning

*Mr. Pandey is an assistant professor of management, Patan Multiple Campus, TU, Nepal 
strategy has three vital constituents: expanding area under cultivation, technological progress, and institutional reforms. Developing countries must expand employment opportunities in the agriculture sector. This can be done by adopting an agriculture planning strategy. The cities need more schools, more hospitals, low-cost housings, wider roads and smooth drainage, uninterrupted clean drinking water supplies, spacious parks and playgrounds and assuring security provisions etc. The villages need building of dams and irrigation canals, construction of roads linking them to cities, schools and colleges, hospitals, electricity, and water supply etc. Public work programs are highly labour intensive in nature and lead directly to substantial increase in employment opportunities. They help in allocating income in favour of the poor. Farmers who have undergone some technical training will be encouraged to set up small-scale enterprises on their own. Financial assistance and other various incentives in the form of cheap raw material availability, knowledge about market conditions, exemption from industrial licensing policy; tax base etc. can be the measures to uplift them. As the process of rural development accelerates, substantial self-employment can be expected to be generated in the field of storage, transport, marketing, distribution of Agro-product, maintenance and repair of farm implements and transportation equipments. A large portion of the people who migrate from rural to urban areas in search of employment must resort to odd jobs like newspaper selling, shoe polishing, car washing etc. In the initial period of development, as the migration of rural people to urban areas increases, rapid expansion takes place in the traditional and unorganized sectors. There is a shift in the employment composition from primary sector to the service sector and manufacturing sector as modern services expand. As modern economic development precedes public administration, commerce, finance, transportation, and communications, teaching and tourism etc. may attract many unemployed youths for the new attractive jobs. Economic growth and rate of employment have positive relations, but productivity of workers inversely affect the employment growth (Melamed, Hartwig and Grant).

\section{Objectives of the study}

i) To highlight the importance of growth to employment;

ii) To access the relationship between employment and economic patriotism.

\section{Review of literature}

The performance in growth and employment of Bangladesh, India and Nepal is found moderate, high, and low respectively in terms of growth and rapid growth, increased slow growth and uncertain and slow growth respectively in terms of employment (Kaspos).

Growth in the service sector provides more jobs per percentage increase in growth rates globally than growth in either agriculture or manufacturing sectors. Country studies by the United Nations Research Institute for Social Development (UNRISD) indicate that the proportion of working poors in the formal sector in manufacturing might be higher than in the service sector (UNRISD).

A better understanding of the relationships between economic sectors and the dynamics of firms and workers within the informal sectors is essential to improve policy on growth and 
employment. In Africa as a whole, formal sector employment is a small minority of all employment and without policies which work for the informal sector too, employment policy will be at best ineffective and at worst counterproductive (Heintz and Pollin).

The employment elasticity in developing countries is found to be 0.7 (Khan). He meant one percent increase in GDP results 7 percent increase in employment. He posits that rapid economic growth is necessary for a high rate of expansion of productive and remunerative employment. The employment intensity of overall economic growth is an issue that merits in-depth study and analyses by reason of its direct impact on economic policies in Nepal. Policy makers use a set of indicators, to create sufficient jobs to absorb new candidates to the labour market. These indicators include employment elasticity with respect to output, unemployment rates, rates of participation in economic activity, and ratios of employed persons to the population (Dahal \& Rai, 2019).

Hence, growth in productive employment is limited by the rate of growth in output. Employment growth in excess of the growth rate of output is possible at the cost of a decline in the productivity of employment which has an adverse effect on the welfare of the poor.

\section{Methodology}

The researcher uses the secondary data. Secondary data on employment and growth between the periods 1971 to 2017 is taken as empirical evidence in case of Nepal. Descriptive analysis has been inductively made to come to the conclusions.

\section{Results and Discussions}

\subsection{Employment Challenges of Nepal}

Employment challenge in a developing country like Nepal may manifest in several forms. Firstly, there is a quantitative dimension in employment that employment growth may fall short of labour force growth giving rise to open unemployment. Secondly, low productivity earning is associated with a sizeable segment of the employed population. An associated phenomenon is predominance of employment in the informal segments of the economy where productivity and earnings are low, and conditions of work are poor. An important part of employment challenge is to raise the productivity and earnings of the workers through a change in the structure of employment towards sectors with high productivity and raising productivity of workers in sectors characterized by low productivity. The challenge before Nepal is to engender such a process of economic growth where not only output in nonagriculture sectors but also productivity and employment would grow. Rising the productivity of workers emerges as a major issue in addressing the challenge of employment. This brings the two major issues-if output growth is obtained only through productivity growth, employment growth would be low even when output grows at a high rate. Second, there is possibility of a trade-off between growth of employment and labour productivity.

Nepal's monetary policy and fiscal policy are not complementing properly. Lack of compatible monetary and fiscal policy, desired growth is not achieved that would lead to the 
higher employment growth. The following are the major challenges in the labour market:(a) Inadequate structural transformation and diversity, (b) Lack of productive employment (low productivity, low-wages and poor working conditions), (c) Weak education standard and inadequate skill development; use of and search for foreign employment; and diverse barriers for the youth and other social groups. (d) Lack of a labour market information system and labour administration.

\subsection{Employment Situation in Nepal}

According to the National Census 2011, the total population of Nepal is 26.5 million, whereas the sex ratio (number of member 100 women) has come down to 94.2 from 99.8 compared to Census 2001. Majority of population is that of the youth: people below 35 years of age account for nearly 70 per cent of the population. Nonetheless, the major challenge is how to benefit from this huge population. The National Youth Policy, 2066 defines persons between 16 and 40 years of age as youth. By this definition, the youth account for nearly 40 percent of the population. According to the Nepal Labour Force Survey (Central Bureau of Statistics), the population above 15 years of age in employment was 11.78 million, which shows a 2.2 percent growth in employment generation over NLFS, 1998. The average ratio in employment is estimated at 81.7 percent, with 85.5 percent for men and 78.5 percent for women. The labour force participation rate in urban areas is quite low compared to rural areas; 67 percent in urban areas and 84 percent in rural areas. Participation rate in employment is higher for male, that is 80.9 percent compared to female’s 79.4 percent.

During 1998/99-2008, population has grown at an annual growth of 2.6 percent while employment has grown at the rate of 2.4 percent. As a result, open unemployment has gone up from 1.8 percent in the same period to 2.2 percent in 2010. While the overall unemployment rate was not so high, urban unemployment rate was 7.5 percent in 2008, indicating that open unemployment is basically an urban phenomenon. Given the growth of labour force, 4,50,000 laborers enter in labour market every year (Central Bureau of Statistics). This figure indicates the quantitative dimension of the employment challenge in Nepal. It appears that the structure of the economy in the share of agriculture to GDP has declined substantially overtime from 47.08 percent in 1985/86 to 36.7 per cent in 2008/09. The contribution of manufacturing sector to GDP shifted from 9 percent in 2000/01 to 6 percent in 2012/13. The magnitude of the change in the structure of employment has been even less. Since the inception of privatization and liberalization policy in Nepal, Nepalese entrepreneurs have been run in deteriorating condition. The units providing job to at least 50 workers were 4271 but it has been reduced to 4073 in 2011/12 providing jobs to the same number of workers. The total jobs created in 2011/12 by those units were 2,13,000 but that has been reduced to $1,94,000$ in the same period. The share of agriculture in total employment declined from 81.23 per cent in 1990/91 to 64 percent in 2010/11. The share of employment in manufacturing sector increased marginally from 2.56 percent to 9.27 percent 
during the same period. The trend towards service sector-oriented change was 14.87 percent to 24.02 percent in the given period. Moreover, productivity of employment in manufacturing has declined because of the higher share of employment without an increase in share of output. Annexes (1,2 and3) show the domestic data relating to GDP, GDP growth, employment, employment growth and distribution of population.

\subsection{Economic patriotism}

Most of the Nepalese people are accustomed to the word patriotism in political parlance. In politics, patriotism implies hurling stones to the neighbouring countries and chanting epithets against them to safeguarding the native country from foreign domination or attack. It teaches people to rise and fight for the interest of homeland. It comes under natural duties of the people residing in a specific territorial boundary. People's basic needs remain unsolved, poverty engulf people due to unemployment, inequality diversified, cost of living surmounted and so on. It is because of the state being indifferent about the reality; statesmen and planners are turning deaf ears towards economic patriotism. Even the economic scholars are fond inimical to the word 'patriotism' stating that it come under political terminology. Economic patriotism aims to implement a regulatory and innovative system of economic activity that causes positive benefit from the development of enterprises in terms of growth. Employment is triggered and major decision- making centres are held in proper order.

It is important to stress that economic patriotism makes only sense if it is based on competitiveness, the innovating power of national enterprises and universities. Economic patriotism must be interpreted as the will to reinforce the strategic autonomy of a country, to multiply the synergies between national actors to enhance their development, to give a country through its actors (enterprises, state institutions, financial sector, universities) the capacity to take advantage of opportunities and to resist threats (by anticipating them and producing adapted responses) as a result of the new dynamics generated by globalization. Economic patriotism allows us to build a common culture of power and national success; a shared vision of challenges and issues; and a precise perception of threats and opportunities. Within this perspective the mission of the state is to anticipate the future and to create a conducive atmosphere for the achievement of national power. The protection of strategic enterprises is the first objective of economic patriotism. It is possible to speak of the national interest. Modern economies are not just based on large enterprises but also on SMEs that represent the industrial network of a country and a considerable potential for innovation. Economic patriotism means helping SMEs develop within a competitive environment so that they can reach a critical size necessary to go and hunt up external markets. So, people need to understand that no social cohesion can be implemented without 
a national strategy based on an intelligent economic patriotism concerned with the reciprocity of commercial and financial behaviour.

\section{Conclusion}

\subsection{Importance of economic patriotism}

Employment patriotism (EP) is the linking term that unites employment and economic patriotism. It has been a long way that the Nepalese people have been craving and sacrificing for political changes. There has been great deal of political literacy to make people aware of their freedom and national integrity. But their socio-economic condition has not basically changed. So, it is high time to make statesmen and policy makers aware about employment patriotism. Economic patriotism must be linked with employment. Every government action is needed to be guided by employment generation motives. The more you employ, the more successful you become. Even the private and government sector policies need to be incorporated to generate high employment. Government can motivate, convince, and compel these sectors to thrive employment. The entire Public Private Partnership (PPP) model adopted by the Government of Nepal after the enactment of the Constitution of Nepal in 2015, should be directed towards generating employment. In order to generate more employment at home, it needs higher growth rates. For higher growth rates to be achieved, government stability must be guaranteed. For government stability, the policy of economic patriotism must be internalized by all political parties. Once this policy has been adopted, large number of youths going abroad for the search of jobs could be called gradually back. It helps utilizing indigenous resources. The youths could be deployed for different sectors for productive purposes. They create aggregate demand at native place side by side more output can be produced. For this, judicial blend of fiscal and monetary policy is warranted.

\subsection{Validity}

As per the NLFS (2017/18), the national unemployment rate is $11.4 \%$; and unemployment is predominantly an urban phenomenon with $70.5 \%$ of the unemployed residing in urban areas (Central Bureau of Statistics). The unemployment rate is high especially among the younger population, $38.1 \%$ for the $15-24$ age group and $31.1 \%$ for the $25-34$ age groups. Several push and pull factors influence a high volume of Nepalese to migrate abroad for temporary overseas employment. As a result, around 64, 00,000 of Nepalese youths are approved for foreign jobs (National Planning Comission). National Population and Housing Census indicates that almost $50 \%$ of the households in Nepal has at least one member who is either working overseas or has returned from foreign employment recently (Central Bureau of Statistics). During COVID-19, a crisis of global magnitude that has simultaneously impacted all countries worldwide. It is estimated that a total of 3,210,848 Nepalese are currently residing in destination countries. Looking at the volume of migrant workers who 
want to return, i.e., 4,25,356 workers, $60 \%$ are expected to be returning due to COVID-19 i.e., 255,213 . This is a significant volume of returnees who will need to be accommodated in the domestic labour market in Nepal. In addition to the increased pressure due to an unprecedented volume of COVID-19 induced returnees, the economic downturn due to the pandemic may also reduce the global demand for migrant workers. This means that aspiring migrant workers who would have otherwise opted for overseas employment are unable to do so. In such an alarming case, Nepal needs to prepare for employment patriotism policy. Nepal must have wider vision about how and where migrant workers will be accommodated and how to settle annual job seekers who enter the labour market. A thorough and comprehensive employment policy urgently needs to be incorporated. So, employment patriotism is inevitable to resolve present crisis.

\subsection{Generality of conclusion}

Nepal's all policies need to be redirected towards linking between employment and economic patriotism. Economic patriotism policy must be targeted to generating higher employment. For this, GDP growth rate has to be accelerated. In order to achieve higher growth rate, employment patriotism (EP) policy must be incorporated in Nepalese policy frameworks. So, employment patriotism (EP) is the judicial blend of employment and economic patriotism. Government of Nepal will be highly appreciated to initiate employment augmenting schemes such as: (i) an increase in wage employment; (ii) an increase in real earning from wage employment; (iii) an increase in self-employment; (iv) an increase in the productivity of employment; and (v) an improvement in the terms of exchange for the produce of the poor both in wage employment and in self -employment. For these to materialize, the following steps need to be initiated:

- Introduction of Employment Patriotism (EP) approach which is believed to boost up employment rooted with economic growth and stability.

- EP friendly monetary and fiscal policies are to be incorporated.

- Structural transformation is to be ignited.

- Proper trainings and social security schemes are required to be introduced.

- In order to meet the target of Sustainable Development Goals by 2030, the PPP model of Nepal has to be coined with employment patriotism.

Annex-1

Table 1: Employment and GDP Growth of Nepal

\begin{tabular}{|c|c|c|c|}
\hline Year & EAP & $\begin{array}{c}\text { Real } \\
\text { GDPGrowth }\end{array}$ & Employment \\
\hline 1971 & 41.9 & - & 9.34 \\
\hline 1981 & 45.6 & 3.8 & 9.07 \\
\hline 1991 & 39.7 & 4.8 & 21.41 \\
\hline 2001 & 42.8 & 5.6 & 24.63 \\
\hline 2011 & 37.5 & 3.7 & 27.47 \\
\hline 2017 & 38.5 & 7.74 & 34.2 \\
\hline
\end{tabular}


Source: NLFS, CBS, 2001 to 2017

\section{Annex-2}

Table 2: GDP and GDP Growth of Nepal in Different Years

\begin{tabular}{|c|c|c|}
\hline Year & $\begin{array}{c}\text { GDP in constant } \\
\text { Price (Rs. } \\
\text { Billion) }\end{array}$ & GDP growth \% \\
\hline $2009 / 10$ & 1192.8 & 4.26 \\
\hline $2010 / 11$ & 1367.0 & 3.85 \\
\hline $2011 / 12$ & 1527.3 & 4.61 \\
\hline $2012 / 13$ & 1695.0 & 3.76 \\
\hline $2013 / 14$ & 1964.5 & 5.72 \\
\hline $2014 / 15$ & 2130.1 & 2.97 \\
\hline $2015 / 16$ & 2674.5 & 20 \\
\hline $2016 / 17$ & 3031.0 & 7.70 \\
\hline $2017 / 18$ & 3464.03 & 6.30 \\
\hline
\end{tabular}

Source: CBS/ Nepal, 2017

Annex-3

Table:3 Employment Ratio of Nepal

\begin{tabular}{|cl|}
\hline Descriptions & \\
\hline$\bullet$ & Total Employment: 7086 thousand \\
\hline$\bullet$ & Total Unemployed: 908 thousand \\
\hline$\bullet$ & Total Labour Force: 7994 thousand \\
\hline$\bullet$ & Not in Labour Force: 12750 thousand \\
\hline$\bullet$ & Total Active Work force in Nepal: 20744 thousand \\
\hline$\bullet$ & Labour Force Participation Ratio: 38.5 \\
\hline$\bullet$ & Employment to population Ratio: 34.2 (Male: 48.3, Female: 22.9) \\
\hline 36.5) & Formal Sector Employment: 37.8 (Agriculture: 1.3, Non-Agriculture: \\
\hline$\bullet$ & Informal Sector Employment: 62.2 (Agriculture: 20.2, Non-Agriculture: \\
\hline 41) & \\
\hline Informal Sector Employment out of Employed: 84.6 \\
\hline
\end{tabular}

Source: NLFS, CBS,2001 to 2017

\section{References}

Central Bureau of Statistics. National Population and Housing Census 2011. Kathmandu: Central Bureau of Statistics, 2012.

—Nepal Labour Force Survey 2008. Kathmandu: Central Bureau of Statistics, 2009.

- Report on the Nepal Labour Force Survey, 2017/18. Kathmandu: Central Bureau of Statistics, Nepal, 2019. 
Dahal, M. P. and H. Rai. "Employment Intensity of Economic Growth: Evidence from Nepal." Economic Journal of Development 27 \& 28, No 1-2. Combined (2019).

Ernst, C. "Promoting Youth Employment." Poverty in Focus (2008).

Heintz, J. and R. Pollin. Targeting Employment Expansion, Economic Growth and Development in Sub-Saharan Africa: Outlines of an Alternative Economic Programme for the Region. Addis Ababa: UNECA, 2008.

Higgins, K. "Are we missing a trick on employment, development policy and poverty reduction?" ODI Opinion 124 (2009).

Kaspos, S. "The employment intensity of growth: trends and macroeconomic determinants." Employment Strategy Paper (2005): 12.

Khan, A.R. "Growth, employment and poverty: An analysis of the vital nexus based on some recent UNDP and ILO/SIDA studies.” U.N. DESA Working Paper No. 49 (2007).

Melamed, Claire, Renate Hartwig and Ursula Grant. "Jobs, growth and poverty: what do we know, what don't we know, what should we know?” Background Note (2011).

National Planning Comission. The Effects of COVID-19 Pandemic on Foreign Employment and its Impact on the Economy of Nepal. Kathmandu: Government of Nepal, National Planning Comission, 2020.

UNRISD. Combating Poverty and Inequality: Structural Change, Social Policy and Politics. Geneva, 2010. 